\title{
The Burial System at Pacung
}

\author{
Marini Drawatik
}

\section{Introduction}

A burial system is a set of elements which are regularly related to one another in such a way that a totality, including procedures, methods, ceremonies and everything related to burial, is formed. The activities related to the burial cover the maintenance and preparation of the corpse, the making of offerings, the ceremonies necessary and the implementation of the burial. All these activities need accurate management and a detailed listing of all the tasks to be performed because they involve most or all of the community members (Binford 1972:232-400; Soejono 1977:9-10). In a burial system there are some particular rules related to the position of the corpse, the container used, the accompanying provisions for the dead person and everything related to the ceremony (Wirastri 1990:5-6).

A cemetery is part of an activity area since burials are repeatedly carried out there and since it forms a structure of activities of a particular social group belonging to a definite settlement (Binford 1972:146; Aziz 1987:158-160). The choice of a settlement area is, at least in prehistoric times, very much related to the adaptation of people to their environment, the availability of water and the other facilities needed such as means of transportation as well as natural resources that can supply foodstuffs (Tim Jurusan Arkeologi 1998:8). The reason why people in the prehistoric era chose the region of Pacung can be found in the favourable environmental conditions for human survival. It is located at the estuaries of several 
rivers close to the coast and forest. The location was able to supply an abundance of fresh water, all maritime produce (fish, salt etc.) and other natural resources (see Suastika this volume).

The earlier researches conducted at the Pacung site in 1987 and 1989 found fragments of pottery both local and made in India and China, animal bones and some compositions of stones indicating the construction foundations built in the past. This reveals that the Pacung site was considered a complex settlement (see Ardika and Suastika this volume). Related to the burial, I Wayan Ardika, in his dissertation, mentioned two findings of human skeletons in trench SBN VII (excavation trench Sembiran VII). The first skeleton was found flexed in an east-west position with face southwards. Its arms and legs appeared to be folded. Some beads, possibly functioning as grave goods (Ardika 1991:37), were associated with the first skeleton. The second skeleton was in a flexed position as well but only some remains and leg bones were found. In the following years several skeletons with different positions, directions and orientations were found.

\section{The Prehistoric Burial Patterns}

According to R.P. Soejono, the prehistoric burials consisted of a number of different patterns. The main patterns of burials are as follows:

1. The primary burial can be classified into the burial without any container (Soejono 1977:92), and the burial with permanent container such as a jar, a stone room, dolmen or sarcophagus in which the corpse was placed (Soejono 1969:2).

2. In the secondary burial all or parts of the bones were buried with or without containers such as jars or sarcophagi. The bones were not anatomically placed, but looked mixed or incomplete; however they showed a particular pattern (Soejono 1969, 1977).

3. A mixed burial system consisted of both primary and secondary burials.

4. In an open burial system the corpse was exposed on the ground at a particular area such as at coral cliffs, cave walls, big stones, big trees and so on (Sudiono 1985:66). The open burial was usually followed by a selective one in which half the bones were buried under the ground or were put in a particular container as can be seen at Toala (South Sulawesi) and Trunyan (Central Bali).

Based on the prehistoric patterns of burial generally mentioned above, the prehistoric patterns of burial at the Pacung site can be described as follows:

\section{Burial Container}

In trench PCN IV (excavation trench Pacung IV) a closed jar containing human remains was found; thus evidence of a secondary burial $(\mathrm{S} \mathrm{X})$ is present. The skull was directed towards the sea. Adjacent to the nearby Ponjok Batu temple, a sarco- 
phagus serving as a burial container (primary burial) was also found. The sarcophagus was made of sandstone and a small amount of andesit stone. Those who were primarily and secondarily buried with sarcophagi and jars as containers probably had high social status and important positions (Mahaviranata 2002:23).

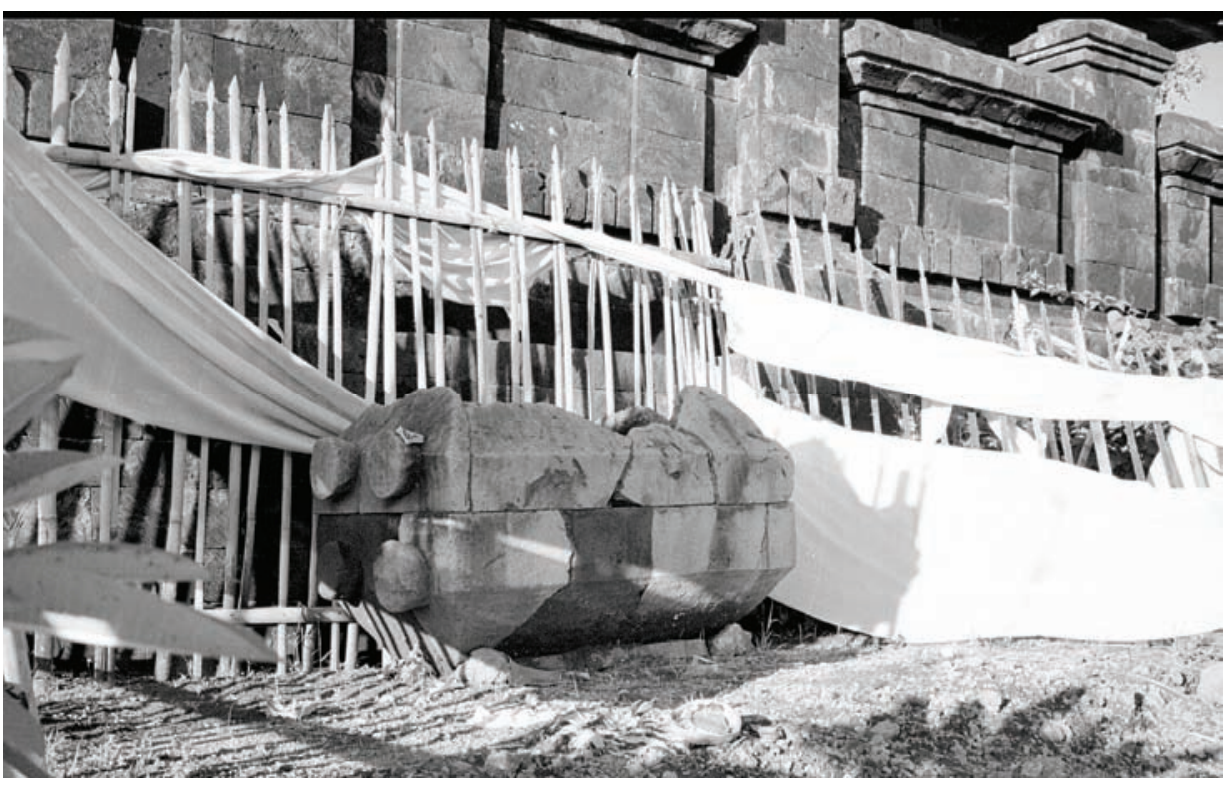

Photo 1: Sarcophagus found at the Ponjok Batu Temple. Photo: Brigitta HauserSchäublin 1999.

\section{The Position of the Bodies}

The human skeletons found from the excavation at the Pacung site until 2004 totalled 10 derived from PCN III and PCN IV (see Table 1; Ardika this volume). Half the skeletons were found complete with the bones still anatomically related and the other half were found in an incomplete state. Incisor, canis, molar and premolar, some fragments of backbones (vertebra), and fragments of ribcages and of skulls were also found.

Skeleton I (S I) was found in trench PCN III at spit 35 and $360 \mathrm{~cm}$ under the earth's surface. This skeleton was put on a clay layer mixed with rough sand blackish brown in colour. Not all the skeleton, but merely some fragments mixed and caught under natural stones were visible. The fragments were not anatomically related. The fragments in S I were not regularly piled and no skull was found; the orientation of the corpse could therefore not be identified.

Skeleton II (S II) belonged to an adult individual found at $385 \mathrm{~cm}$ under the earth's surface and at a clay layer mixed with sand. The arms were flexed (flexed position) with the lower arms folded up under the shoulders. The body was found 
complete with the bones in an anatomically correct position, except for the feet, which may perhaps be located in the wall of the excavation trench. The corpse had been buried straightaway without any permanent containers.

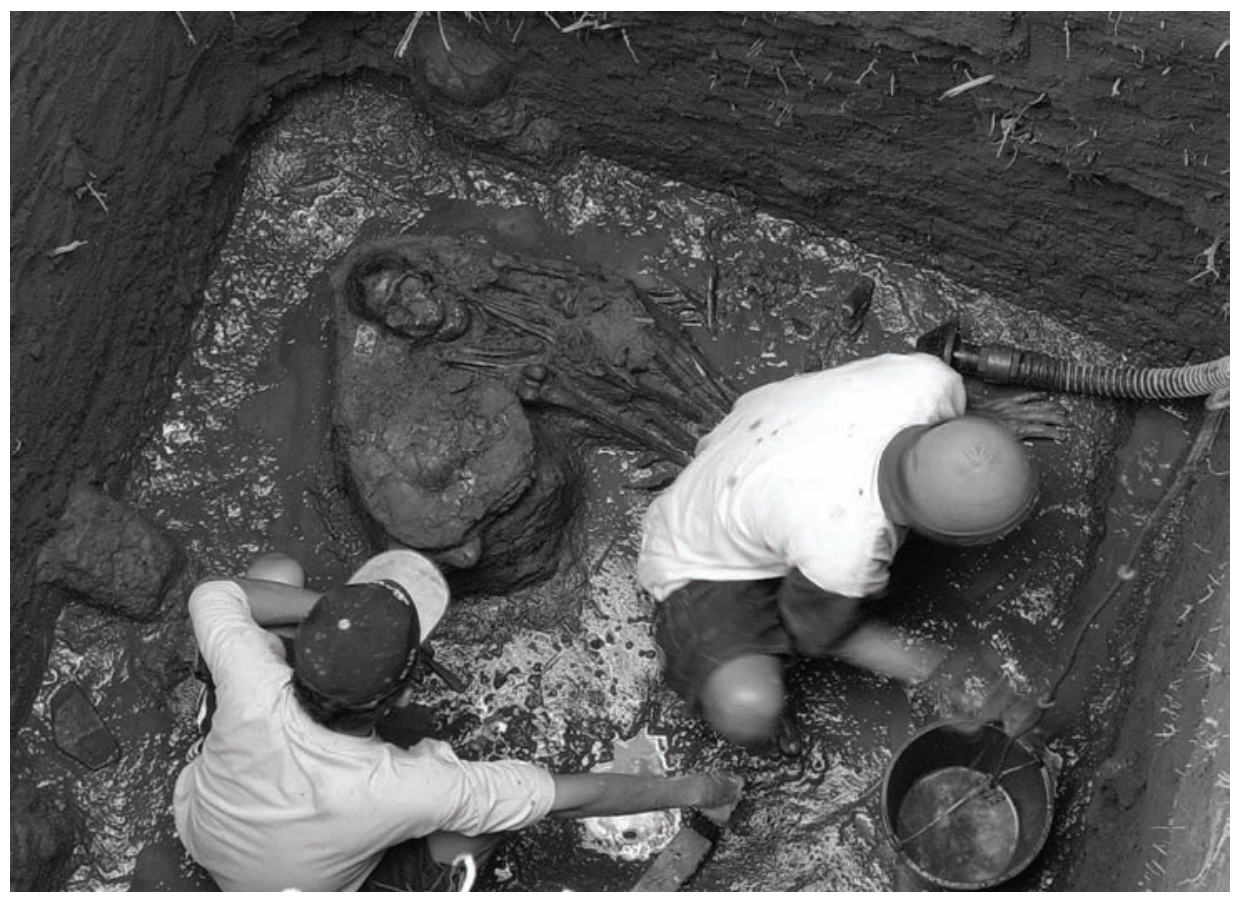

Photo 2: The excavation site Pacung IV with a skeleton in a flexed position and a jar containing a skull adjacent to the skeleton. These finds were located $400 \mathrm{~cm}$ below the ground surface and the sea level. The bottom of the trench had to be continuously drained.

Photo: Brigitta Hauser-Schäublin 2004.

As the careful analyses showed, the bones from what was first identified as Skeleton III (S III) and Skeleton IV (S IV) probably belong to one individual because they had the same colour and were found close to each other. They were located at $390 \mathrm{~cm}$ under the earth's surface. S III consisted only of a skull which was found undamaged. S IV included bones of legs that probably belonged to the same skeleton as the skull. These remains suggest an uncovered secondary burial. After the corpse had decayed, some bones considered important had been selected for burial. Parallel to the skull (S III), fragments of local pottery red in colour and forming part of burial provisions were found.

Skeleton V (S V) belonged to an adult individual which was located in PCN IV. S V consisted only of a damaged skull. The body of S V apparently became 
separated from the skull. It may perhaps be located in the wall of the excavation trench. To the north of S $\mathrm{V}$ a damaged clay pan was found.

Skeleton VI (S VI) was found in PCN IV lying in a flexed position. The skull appeared to be undamaged, the arms were folded up under the shoulders and the feet were in a squatting position. The whole body was slanted to the right. On the right side of S VI, parallel to its head a closed jar was found. The burial of a flexed body in the prehistoric era may have been based on the belief that a corpse should be in a similar position as a baby in his mother's womb. This possibly is an indicator for the belief in rebirth (Mahaaviranata 2002:22).

Skeleton VII (S VII) was located in trench PCN IV at a depth of $400 \mathrm{~cm}$ under the earth's surface. Only arm-bones could be discovered. The other findings were in the form of six bronze bracelets (two of them were found worn on the wrist and four off the wrist but still close to the arms).

Skeleton VIII (S VIII) was found in PCN IV at $425 \mathrm{~cm}$ under the earth's surface. Most the bones were not anatomically related and were in bad condition. Nevertheless, the skeleton gives evidence of a primary burial without permanent container.

Skeleton IX (S IX) was located in trench PCN IV at spit 43 which was $230 \mathrm{~cm}$ below the surface. While half the bones were in bad condition, the other half appeared to be undamaged and anatomically related. Some fragments of a skull were found to the north and the feet were found to the south. There were three clay pans found to the left, parallel to the head. A comparative point of view of S VI and S IX leads to the conclusion that this site was a multiple burial site. First, S IX was buried followed by S VI but at the same location. In the process of the burial, S IX was dug up, either intentionally or unintentionally, so that there was enough space for the relocation of S VI. This could be the reason for the damage to S IX. Similar circumstances can be found at several prehistoric burial sites such as at the Gilimanuk Site and Gunung Wingko Site, South Central Java (Simanjuntak 1979:61).

Skeleton X (S X) was found inside a jar, which at first was assumed to be grave good for S VI. After the jar was lifted, a skull was discovered; S X indicates a secondary burial with a permanent container

A careful examination revealed an anatomical difference between S I and S X with regard to the teeth and other parts of the body. One skeleton displayed apparent traces of tooth-filing. This was shown by a loose finding in the form of fragments of incisors in trench PCN IV. On the fragments of teeth some filing marks were seen that were probably applied during a life cycle ceremony, the transition from childhood to adulthood (Simanjuntak 1979:66-67). 
Table 1: Description of Findings of Human Remains

\begin{tabular}{|c|c|c|c|c|c|c|c|c|c|c|c|c|c|c|c|c|c|c|c|}
\hline \multirow[t]{2}{*}{ No } & \multirow[t]{2}{*}{$\begin{array}{l}\text { Skele- } \\
\text { ton }\end{array}$} & \multicolumn{2}{|c|}{$\begin{array}{l}\text { Posi- } \\
\text { tion } \\
\text { of } \\
\text { the } \\
\text { body }\end{array}$} & \multicolumn{2}{|c|}{$\begin{array}{l}\text { Posi- } \\
\text { tion of } \\
\text { the legs }\end{array}$} & \multicolumn{2}{|c|}{$\begin{array}{l}\text { Posi- } \\
\text { tion of } \\
\text { the } \\
\text { arms }\end{array}$} & \multicolumn{6}{|c|}{ Condition of skeleton } & \multicolumn{6}{|c|}{ Types of burial } \\
\hline & & $\mathrm{a}$ & $b$ & C & $d$ & e & $f$ & 1 & 2 & 3 & 4 & 5 & 6 & $A$ & $B$ & C & $D$ & $E$ & $\mathrm{~F}$ \\
\hline 01 & S.I & & $X$ & & $X$ & & & & & & & & $x$ & & & & & & $X$ \\
\hline 02 & S. II & $\mathrm{X}$ & & & $X$ & $X$ & & & $X$ & & & & & $X$ & & & & $X$ & \\
\hline 03 & S. III & & $X$ & & $X$ & & $X$ & $X$ & & & & & & & $X$ & & & & \\
\hline 04 & S. IV & & $x$ & $x$ & & & $X$ & & & $X$ & & & & & $B$ & & & & \\
\hline 05 & S. V & & $X$ & & & & $X$ & $X$ & & & & & & & & & & & $X$ \\
\hline 06 & S. VI & $x$ & & $X$ & & $X$ & & & $X$ & & & & & $X$ & & $x$ & $\mathrm{D}$ & & \\
\hline 07 & S. VII & & $X$ & & $X$ & & $X$ & & & & $X$ & & & $A$ & & & & & \\
\hline 08 & S. VIII & & $X$ & & $X$ & & $x$ & & & & & & $\mathrm{X}$ & & & & & & $X$ \\
\hline 09 & S. IX & & $x$ & & $X$ & & $x$ & & & $X$ & & $X$ & & $X$ & & & $X$ & & \\
\hline 10 & R. X & & $X$ & & $X$ & & & $x$ & & & & & & & & $X$ & & & \\
\hline \multicolumn{4}{|c|}{$\begin{array}{l}a=\text { stretched out } \\
b=\text { unknown } \\
c=\text { legs flexed } \\
d=\text { unknown } \\
\text { e }=\text { arms flexed } \\
\mathrm{f}=\text { not identified }\end{array}$} & \multicolumn{8}{|c|}{$\begin{array}{l}1=\text { skull } \\
2=\text { bones still in original } \\
\quad \text { anatomical position } \\
3=\text { leg bones } \\
4=\text { arm bones } \\
5=\text { damaged bones } \\
6=\text { fragments, mixed }\end{array}$} & \multicolumn{8}{|c|}{$\begin{array}{l}\mathrm{A}=\text { primary burial with- } \\
\text { out permanent con- } \\
\text { tainer } \\
\mathrm{B}=\text { secondary burial } \\
\mathrm{C}=\text { mixed burial } \\
\mathrm{D}=\text { double burial } \\
\mathrm{E}=\text { single burial } \\
\mathrm{F}=\text { not identified }\end{array}$} \\
\hline
\end{tabular}

\section{Orientation of the Skeletons}

The dominant direction of the skeletons found at the Pacung site was north-south with the head facing southward. "South" points at the mountains or hills where, according to today's understanding, the ancestors' souls are supposed to reside. Such a direction was found in S II and S VI. The skeletons were positioned slightly aslant to the left with the heads facing the south-west. The fact that the faces were slightly aslant was possibly caused by the pressure of the ground around the head.

Contrary to the position of S II and S VI, the heads of S III and S IV, which were supposed to be the secondary burial, faced north-east, the direction to the sea. The belief that the sea is the residence of the ancestors' souls is often found in the Indonesian ethnic groups residing in the coastal regions.

The skeleton S V laid south-west with the face towards north-east. What might be the reason for this position? Was the deceased a member of a different cultural community with other notions of orientation? Or might it have been an unusual death? 
Another possibility might be that the dead person had come from another region, with the burial pointed toward his place of origin (Soejono 1977:190, 263).

The skull of S X was directed to the north and slightly to the north-east.

Table 2: The Orientation of the Bodies

\begin{tabular}{|c|c|c|c|c|c|}
\hline No & Skeleton & Orientation & $\begin{array}{l}\text { Position of the } \\
\text { Head }\end{array}$ & $\begin{array}{l}\text { Direction of } \\
\text { the Head }\end{array}$ & Description \\
\hline 01 & SI & Unidentified & Unidentified & Unidentified & $\begin{array}{l}\text { Bone fragments } \\
\text { which were mixed } \\
\text { and pressed by } \\
\text { some stones }\end{array}$ \\
\hline 02 & S II & North-south & South & $\begin{array}{l}\text { Looking to the } \\
\text { right }\end{array}$ & $\begin{array}{l}\text { The feet may } \\
\text { perhaps be lo- } \\
\text { cated in the wall } \\
\text { of the excavation } \\
\text { trench (unidenti- } \\
\text { fied) }\end{array}$ \\
\hline 03 & S III & $\begin{array}{l}\text { North-east/ } \\
\text { North-west }\end{array}$ & Northwest & $\begin{array}{l}\text { Facing north- } \\
\text { east }\end{array}$ & Only a skull \\
\hline 04 & SIV & Unidentified & Unidentified & Unidentified & $\begin{array}{l}\text { Only foot bones of } \\
\text { S III }\end{array}$ \\
\hline 05 & S V & North-west & Unidentified & $\begin{array}{l}\text { Looking to the } \\
\text { left }\end{array}$ & $\begin{array}{l}\text { A damaged skull } \\
\text { propped against } \\
\text { the wall }\end{array}$ \\
\hline 06 & S VI & North-south & South & $\begin{array}{l}\text { Straight to the } \\
\text { front }\end{array}$ & $\begin{array}{l}\text { Body slanted to } \\
\text { the right, probably } \\
\text { multiple and } \\
\text { mixed burials }\end{array}$ \\
\hline 07 & S VII & Unidentified & Unidentified & Unidentified & $\begin{array}{l}\text { Arm bones point- } \\
\text { ing north-south } \\
\text { and bronze brace- } \\
\text { lets as burial } \\
\text { provision }\end{array}$ \\
\hline 08 & S VIII & $\begin{array}{l}\text { North-east/ } \\
\text { North-west }\end{array}$ & North-west & Unidentified & $\begin{array}{l}\text { Skeleton found } \\
\text { intact }\end{array}$ \\
\hline 09 & S IX & North-south & South & Unidentified & Multiple burial \\
\hline 10 & $S X$ & - & - & $\begin{array}{l}\text { Facing the } \\
\text { sea }\end{array}$ & $\begin{array}{l}\text { Secondary burial } \\
\text { with container }\end{array}$ \\
\hline
\end{tabular}

\section{Grave Goods}

The excavations at Pacung showed that all skeletons were accompanied by a variety of gifts. The objects often found in the primary as well as in the secondary burial consisted of ritual tools, ornaments, weapons, tools, symbols of wealth and remains of domestic animals. 
The results of the excavation and analysis showed that at Pacung the grave goods of S II, S VI and S VIII were in the form of loose findings; these were beads of various colours, forms and materials, and pottery sherds of different forms such as pans and jars, both of local and Indian origin. Skeletons S III and S IV had clay pans on the right side parallel to the legs. S V had some fragments of a small broken clay pan on the left side of the skeleton. In S IX one clay pan of medium size was found on the left side of the skeleton parallel to the head.

The most conspicuous gifts were bronze bracelets, some of which were found worn and others loose from the arm bone in S VII.

The form and richness of the burial provisions often depended on the status of the dead person and the economic capacity of their relatives conducting the burial ceremony.

\section{The Relation between the Current and the Prehistoric Burial System}

Archaeological and historical evidence (since the mid $19^{\text {th }}$ century) as well as oral history suggest a continuous settlement in the Pacung-Julah-Sembiran region for hundreds or perhaps even thousands of years. Can we assume continuity in some aspects of culture?

An ethnographic comparison with burial practices in today's Pacung may reveal similarities and differences with the prehistoric practices at the same site. An ethnographic investigation into the burial practices therefore formed part of the project.

Burial in Hindu-Balinese culture is a complex activity. It is a system of how to treat a dead person, the corpse and its burial and the ceremonies carried out after the burial procession in order to liberate and purify the soul (Suastika 2002: 1).

The burial ceremony at Pacung consists of three stages:

\section{Treatment of the Corpse}

Today's Pacung community believes that death is a journey to the embang, the eternal world where the souls of those who are dead reside. Birth and death are already determined by Sang Hyang Embang, the Creator (Suastika 2002:2). The holy place belonging to the souls of the ancestors is called pemerajan or sanggah, household temple. This symbolizes the mountain where the souls of the ancestors reside after a purification ceremony has been carried out; the ancestors' souls are then living close to their families and the community. The treatment of the corpse is intimately linked to the belief in a life hereafter.

Before the corpse is brought to the burial ground, the relatives and local community members bath it completely. Then, it is fully dressed and ornamented. Some beauty powder is also polished on it before it is wrapped with white cloth 
and a mat made of palm leaves. After that, the relatives and community members present food (sagi) and water to the deceased. After the food-serving stage is finished, they carry the corpse directly to the cemetery. The equipment needed for bathing the corpse is later thrown away at the cemetery.

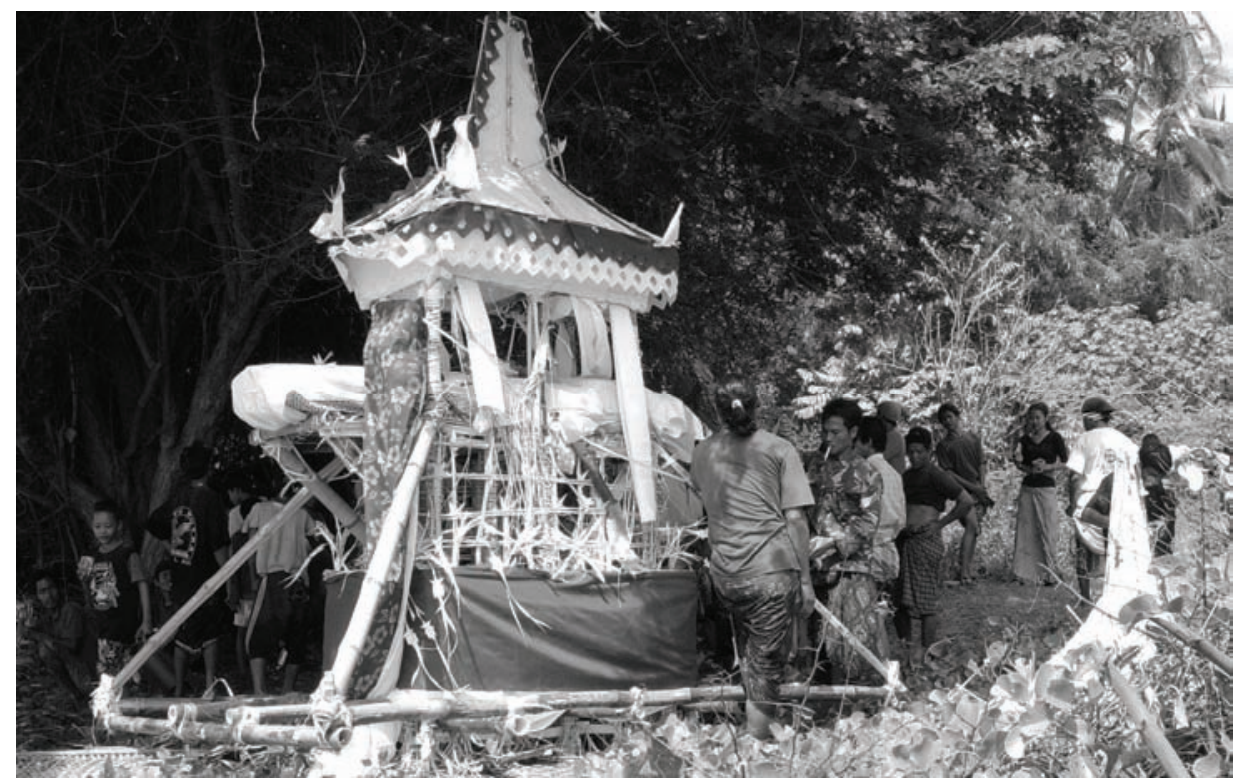

Photo 3: Burial procession Julah. The corpse is wrapped in white cotton cloth and horizontally put on the palanquin. The palanquin is carried by the deceased's relatives to the burial ground.

Photo: Brigitta Hauser-Schäublin 2004.

\section{Burial Procession}

To make the souls reach embang, it is necessary for the relatives and friends of those who are dead to conduct a burial ceremony. A traditional form of burial, according to an informant, was conducted up to 1977, although now some parts have changed. The Pacung villagers carry out a two-fold burial that is, the primary burial (mepegat) followed by the - exclusively symbolic - secondary burial ritual. The primary burial is carried out directly after death, and the second ceremony is conducted 42 days or one month and 7 days after the first one. 


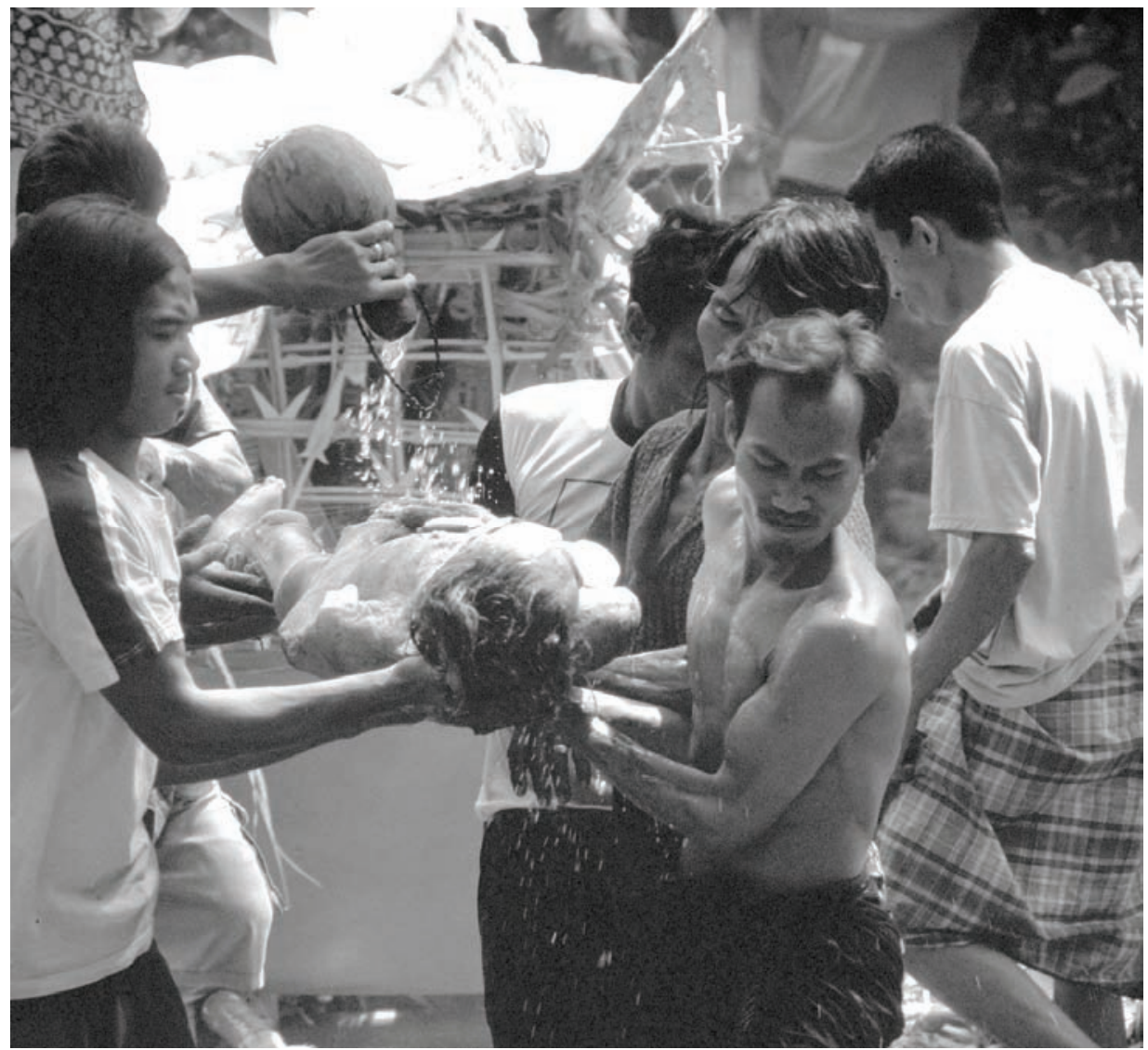

Photo 4: Before the corpse is lowered into the ground it is undressed and washed at the burial place near the sea.

Photo: Enrico Kalb 2004.

At Pacung, if someone dies during the day, the corpse should be buried before the sun sets; if he or she dies during the night, the community should wait for the following day. The ceremony does not have to be carried out on a special day as is done in other communities in Bali. In the event that the relatives live far away and cannot reach their home village within a day, the corpse cannot be kept at home for more than three days.

For the actual burial, a bamboo litter is made, on which the corpse is placed for the mepegat ceremony. This ceremony cuts off the relationship between the dead person and his or her relatives so that they do not object to letting him or her go, having been called by God. This separation is symbolized by white strings of cotton that are cut through by using a small piece of resin that has been set on fire. 


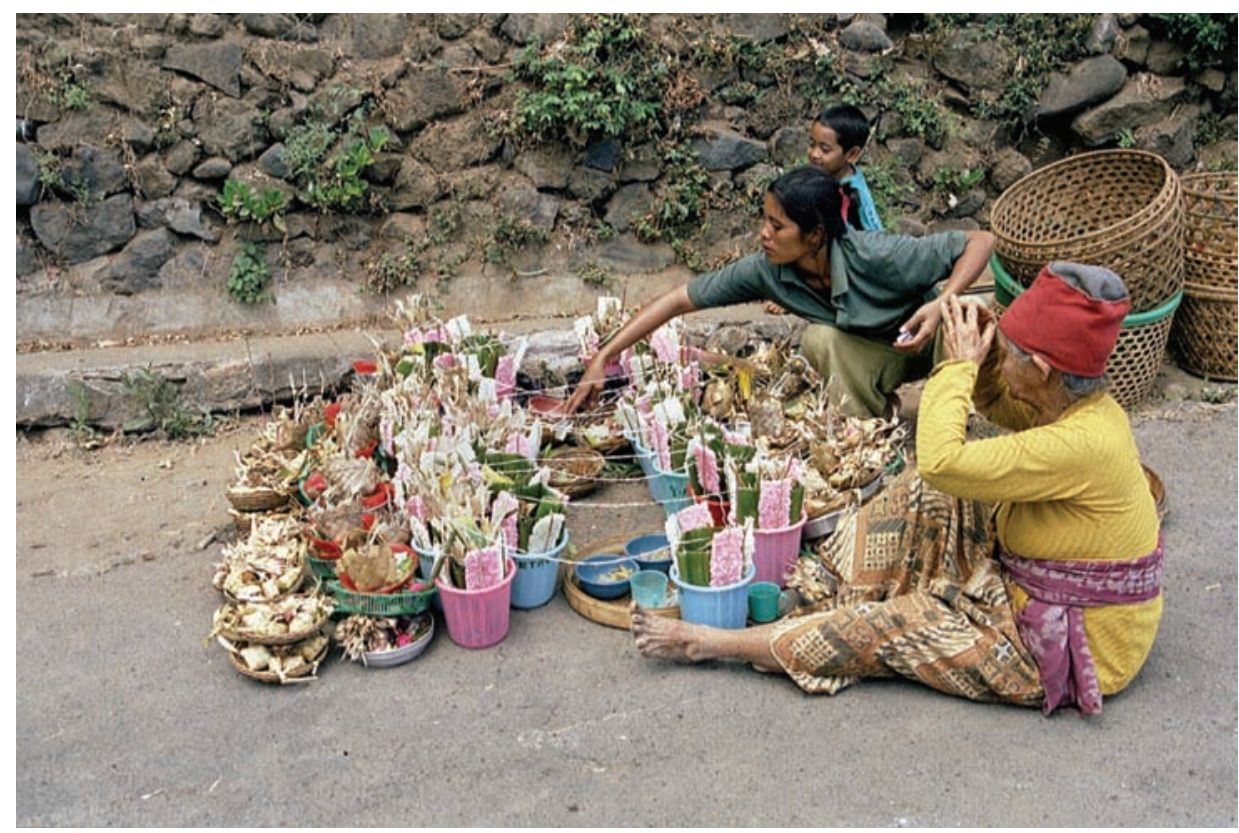

Photo 5: Mepegat Ceremony, the symbolic separation of the deceased from the living by dividing the offerings into two parts (left and right, the latter representing the living) in Sembiran.

Photo: Christian Riemenschneider 2003.

The dead person is provided by the relatives with 11 Chinese coins symbolizing the means of payment for the piece of ground in which the corpse will rest. Sometimes some gold or silver is added. Before the corpse is buried, the 11 Chinese coins and some jambu (Syzygium sp.) leaves are put in the grave and on the corpse. On top of the corpse the relatives put some personal belongings of the deceased as a token of their affection (tresna asik). The corpse is then lowered into the hole and the grave is filled with earth.

The corpse is laid out with the head pointed to the north-east and the feet to the south-west. A male corpse is arranged with the face downward and a female corpse with the face upward. Such positions refer to the belief that male symbolizes the sky and female symbolizes the earth, resulting in fertility or life. However, since 1977 wooden coffins have been used as burial containers at Pacung with the corpse lying stretched out in the same way as described above.

The difference in the orientation of the corpse at Pacung to those in the other regions possibly relates to the Sambu sect, in which death is associated with the north-east, where the God Sambu, who is identical with death, resides.

The grave is marked by stones arranged in the same direction. Finally, the relatives and friends make offerings (sesajen soda) to the deceased. This is intended so that he or she can redeem the mistakes made during his or her lifetime and thus 
give the soul peace (sagi ceremony). The younger relatives pay respect to the deceased (menyumbah) while the older pray (mebhakti).

Before leaving for the cemetery, the dead person's relatives and the community members visit Pura Kahyangan Tiga (the three major village temples), Pura Puseh (Temple of Origin), Pura Desa (Village Temple), Pura Dalem (Death Temple) and finally the family temple to pray.

Eleven days after the burial ceremony they build a permanent grave made of cement to avoid a possible further digging up of the ground for another burial by someone else. In such a case, the corpse would have to be buried together with the old one. If another grave is made, all the ceremonies mentioned above have to be performed again.

\section{The Ceremony of Metuun}

The metuun ceremony is a kind of second burial ritual in which the soul of the deceased is invoked to return; it needs to be purified before returning to embang.

The metuun ceremony is usually performed 42 days after the death if the relatives can afford it. In case they need more time to accumulate wealth for the ceremony, they have to wait for another three or six months, depending on what is decided by the core villagers. Those who are not economically capable are given one year to conduct such a ceremony and the date is set by the village. If they are still unable to perform the ceremony after this year, it is the village's obligation to do so. At the beginning of the ritual, a deity, Bhatara Ratu Gede Dalem, is asked to grant holy water (tirta) so that the deceased (or rather his soul) can be purified. A small manikin (jejeneng) symbolising the deceased is ritually cleansed and then dressed in white at a site dedicated to the dead (merajapati). The soul of the deceased is then called to descend into the jejeneng, which is then carried home and put on the bed of the deceased. There, a purification ritual is carried out. Afterwards, the soul is brought back to the merajapati from where the soul is supposed to return to embang; the jejeneng remains at the merajapati.

\section{Conclusion}

If we compare the prehistoric burial with current practice at Pacung some similarities can be detected, though continuity in populations or culture cannot be assumed. Many fundamental changes have taken place over the past hundreds of years. With regard to the belief system which heavily influences attitudes towards death and life in the after-world, we need to consider the advent of Hinduism and the impact it had on the existing burial system. Nevertheless it is important to state that, traditionally, cremation was not carried out in Pacung. The prehistoric community apparently conducted the primary burial without containers. Nowadays wooden coffins are used, but before 1977 the corpse was merely wrapped in 
mats. However, today the bones are not exhumed after the decomposition of the corpse and put in a special container for a second burial as was done in prehistoric times. Instead, a purification ritual for the soul, metuun, is carried out without touching the corpse again to facilitate the soul's return to embang. Such a ritual leaves no material traces. We know practically nothing about prehistoric life, only the evidence provided by remains.

With regard to the orientation of the corpse we can say that in the prehistoric era the dominant direction was north-south with the head facing southward, while nowadays the orientation of the corpse is north-east, south-west with the head facing north-eastward.

The excavations have shown that the dead were provided with all kinds of goods. This still applies to burials today. If the burial provisions in the prehistoric era were in the form of pottery, beads and metal, those currently used are in the forms of Chinese coins and other things requested by the deceased during his or her lifetime.

\section{References}

Ardika, I Wayan

1991 Archaeological Research in Northeastern Bali. A Thesis Submitted for the Degree of Doctor of Philosophy at the Australian National University. Canberra: Australian National University.

Aziz, Fadila Arifin

1987 Analisis Kubur Situs Plawangan. Proceedings Analisis Hasil Penelitian Arkeologi, Vol. I: 157-177. Jakarta: Pusat Penelitian Arkeologi Nasional: 157-177

Binford, Lewis R.

1972 An Archaeological Perspective. New York: Seminar Press.

Mahaviranata, Purusa

2002 Tingkat Status Social pada Kubur Manikliu, Kintamani, Bali. Pertemuan Ilmiah Arkeologi, Vol. V. Jakarta: Pusat Penelitian Arkeologi Nasional.

Simanjuntak, Harry Truman

1979 Penelitian Desa Pekraman dalam Mewujudkan Jagaditha di Era Globalisasi. Guratan Budaya dalam Perspektif Multikultural. Denpasar: Fakultas Sastra dan Budaya Universitas Udayana.

Soejono, R.P.

1969 On Prehistoric Burial Methods in Indonesia. Bulletin of the Archaeological Institute of the Republic of Indonesia. Jakarta: Lembaga Purbakala dan Peninggalan Nasional.

1977 Sistem-Sistem Penguburan pada Akhir Masa Prasejarah di Bali. Unpublished Dissertation. Jakarta: Universitas Udayana. 
Suastika, I Made

2002 Tata Cara Penguburan di Desa Pacung, Buleleng. Forum Arkeologi. Denpasar: Balai Arkeologi.

Sudiono dan Arfian

1985 Kubur Prasejarah di Liang Bua, Flores Barat. (Analisis Hasil Penelitian Arkeologi Nasional 1978), Skripsi. Jakarta: Fakultas Sastra, Universitas Indonesia.

Tim Jurusan Arkeologi

1998 Ekskavasi Arkeologi di Situs Pacung, Tejakula Buleleng. Laporan Penelitian.

Denpasar: Fakultas Sastra, Universitas Udayana.

Wirastri, Sri

1990 Pola Kubur Tanpa Wadah, Situs Liang Bua, Gilimanuk, Plawangan dan Anyer. Skripsi. Jakarta: Fakultas Sastra, Universitas Indonesia. 